\title{
Water-Worked Bedload: Hydrodynamics and Mass Transport
}

\author{
Paweł M. Rowiński ${ }^{1, *(1)}$ and Subhasish Dey ${ }^{2}$ (I) \\ 1 Institute of Geophysics, Polish Academy of Sciences, Ks. Janusza 64, 01-452 Warsaw, Poland \\ 2 Department of Civil Engineering, Indian Institute of Technology Kharagpur, West Bengal 721302, India \\ * Correspondence: p.rowinski@igf.edu.pl; Tel.: +48-22-182-60-02
}

Received: 5 July 2019; Accepted: 5 July 2019; Published: 7 July 2019

check for updates

Turbulent flow over a natural streambed is complex in nature, especially in the near-bed flow zone, because a natural water-worked bed exhibits a spatially complex, three-dimensional structure [1-3]. This echoes the organization of the bed particles by transport processes. The orientation, imbrication, sorting, and layering of the deposited bed particles are governed by the continual deposition and reworking by several flood cycles. Besides, the bedload transport rate is often predicted from the flow induced bed shear stress with respect to the threshold shear stress, which represents the bed shear stress required for particle entrainment by the flow [4]. Our knowledge on how sediment is transported under such a complex situation is still insufficient, which triggers a good deal of experimental, theoretical, and computational efforts. The near-bed flow is greatly affected by a complex, colossal, fluid-sediment interface giving rise to a spatial flow heterogeneity together with a significant temporal intermittency in the vicinity of the bed. In a natural stream, such a complex flow plays a decisive role in developing its morphological environment. In this process, a so-called water-worked bed is formed in a natural stream. By contrast, in laboratory scale experimental studies, a simulated streambed in a flume is generally created by arbitrarily dumping the sediment particle mixture to a given thickness. The sediment bed surface is then worn and levelled, preparing a screeded bed. Even though if the distribution of sediment particle size used in the laboratory experimental study is same as that of the particle size in a natural streambed, the simulated streambed (bed surface characteristics) cannot be deemed to be acceptable as analogous to that in the natural streambed. To be specific, the screeded bed is essentially a mixture of randomly sorted sediment particles and its statistical distribution in terms of bed surface topography is incompetent to mimic a water-worked bed. The bed surface topography and the flow characteristics in water-worked and screeded gravel beds were explored by several researchers [1,5-12]. However, a series of recent studies by Padhi et al. [13-15] indicated a clear distinction in turbulence characteristics in water-worked and screeded gravel bed flows. Therefore, the research on water-worked beds, in addition to the related hydrodynamics and transport processes, being the topic of this Special Issue, demands further attention.

The application of the water-worked bed concept to fluvial hydraulics is developing rapidly and it has already been successful in a number of laboratory scale model studies, including data analysis and interpretation, and supervising conceptual framework and parameterizations by a number of research groups around the world. To be specific, the impact of water-work on transporting sediment, especially as a bedload, is of primary importance. Moreover, sediment transport by the modification of flow at a river protection structure, such as a groyne or a spur dike, has a detrimental effect of forming a scour hole around it. Therefore, the topic of scours at a river protection structure has been a continued interest of research over several decades. Furthermore, investigators have not been restricted to the laboratory scale model studies. They have been, on several occasions, more interested in conducting field studies in natural streambeds, where the beds are water-worked. This tendency in the current research trend is reflected in this Special Issue. It includes nine papers, which can be classified into four 
categories. The first category is comprised of two review papers from Mrokowska and Rowiński [16] on bedload transport by unsteady flow and Padhi et al. [17] on water-worked gravel beds. These papers deliver an excellent background that is useful for understanding and modeling bedload transport under unsteady flow conditions and for the morphological and flow characteristics in water-worked beds. Both studies are mostly based on experimental investigations. The second category includes studies on river protection structures by Möws and Koll [18] on groynes (one paper) and by Zhang et al. $[19,20]$ on spur dikes (two papers). The former focuses on backwater effect and resistance to flow, and the latter two on scours at spur dikes. Both studies are important from the perspective of designing river protection structures. One paper, by Antico et al. [21], is dedicated to the velocity law in hydraulically rough flow over mobile granular beds, which falls into the third category. The fourth category presents important field studies by Radecki-Pawlik et al. [22] on the Mlynne and Lososina streams in the Polish Carpathians; Huang et al. [23] on the Three Gorges Reservoir (TGR) in China; and Przyborowski et al. [24] on the Jeziorka River and Swider River in Poland.

The Editors finally hope that this Special Issue will be beneficial to advance future research studies and to further develop the water-worked bed concept, including other related issues in laboratory scale models and field studies, and its applications in sedimentology, geophysics, fluvial hydraulics, and environmental and hydraulic engineering.

\section{References}

1. Hardy, R.J.; Best, J.L.; Lane, S.N.; Carbonneau, P.E. Coherent flow structures in a depth-limited flow over a gravel surface: The role of near-bed turbulence and influence of Reynolds number. J. Geophys. Res. 2009, 114, F01003. [CrossRef]

2. McLean, S.R.; Nelson, J.M.; Wolfe, S.R. Turbulence structure over two-dimensional bed forms: Implications for sediment transport. J. Geophys. Res. 1994, 99, 12729-12747. [CrossRef]

3. Maddahi, M.R.; Afzalimehr, H.; Rowiński, P.M. Flow characteristics over a gravel bedform: Kaj River case study. Acta Geophys. 2016, 64, 1779-1796. [CrossRef]

4. Dey, S. Fluvial Hydrodynamics: Hydrodynamic and Sediment Transport Phenomena; Springer-Verlag: Berlin, Germany, 2014.

5. Kirchner, J.W.; Dietrich, W.E.; Iseya, F.; Ikeda, H. The variability of critical shear stress friction angle, and grain protrusion in water-worked sediments. Sedimentology 1990, 37, 647-672. [CrossRef]

6. Nikora, V.; Goring, D.; Biggs, B.J.F. On gravel-bed roughness characterization. Water Resour. Res. 1998, 34, 517-527. [CrossRef]

7. Marion, A.; Tait, S.J.; McEwan, I.K. Analysis of small-scale gravel bed topography during armoring. Water Resour. Res. 2003, 39, 1334. [CrossRef]

8. Aberle, J.; Nikora, V. Statistical properties of armored gravel bed surfaces. Water Resour. Res. 2006, 42 , W11414. [CrossRef]

9. Buffin-Bélanger, T.; Rice, S.; Reid, I.; Lancaster, J. Spatial heterogeneity of near-bed hydraulics above a patch of river gravel. Water Resour. Res. 2006, 42, W04413. [CrossRef]

10. Cooper, J.R.; Tait, S.J. The spatial organisation of time-averaged streamwise velocity and its correlation with the surface topography of water-worked gravel beds. Acta Geophys. 2008, 56, 614-642. [CrossRef]

11. Cooper, J.R.; Tait, S.J. Water-worked gravel beds in laboratory flumes: A natural analogue? Earth Surf. Proc. Land. 2009, 34, 384-397. [CrossRef]

12. Cooper, J.R.; Tait, S.J. Spatially representative velocity measurement over water-worked gravel beds. Water Resour. Res. 2010, 46, W11559. [CrossRef]

13. Padhi, E.; Penna, N.; Dey, S.; Gaudio, R. Hydrodynamics of water-worked and screeded gravel beds: A comparative study. Phys. Fluids 2018, 30, 085105. [CrossRef]

14. Padhi, E.; Penna, N.; Dey, S.; Gaudio, R. Spatially-averaged dissipation rate in flows over water-worked and screeded gravel beds. Phys. Fluids 2018, 30, 125106. [CrossRef]

15. Padhi, E.; Penna, N.; Dey, S.; Gaudio, R. Near-bed turbulence structures in water-worked and screeded gravel-bed flows. Phys. Fluids 2019, 31, 045107. [CrossRef] 
16. Mrokowska, M.M.; Rowiński, P.M. Impact of unsteady flow events on bedload transport: A review of laboratory experiments. Water 2019, 11,907. [CrossRef]

17. Padhi, E.; Dey, S.; Desai, V.; Penna, N.; Gaudio, R. Water-worked gravel bed: State-of-the-art review. Water 2019, 11, 694. [CrossRef]

18. Möws, R.; Koll, K. Roughness effect of submerged groyne fields with varying length, groyne distance, and groyne types. Water 2019, 11, 1253. [CrossRef]

19. Zhang, L.; Wang, P.; Yang, W.; Zuo, W.; Gu, X.; Yang, X. Geometric characteristics of spur dike scour under clear-water scour conditions. Water 2018, 10, 680. [CrossRef]

20. Zhang, L.; Wang, H.; Zhang, X.; Wang, B.; Chen, J. The 3-D morphology evolution of spur dike scour under clear-water scour conditions. Water 2018, 10, 1583. [CrossRef]

21. Antico, F.; Ricardo, A.M.; Ferreira, R.M.L. The logarithmic law of the wall in flows over mobile lattice-arranged granular beds. Water 2019, 11, 1166. [CrossRef]

22. Radecki-Pawlik, A.; Kuboń, P.; Radecki-Pawlik, B.; Plesiński, K. Bed-load transport in two different-sized mountain catchments: Mlynne and Lososina Streams, Polish Carpathians. Water 2019, 11, 272. [CrossRef]

23. Huang, L.; Fang, H.; Ni, K.; Yang, W.; Zhao, W.; He, G.; Han, Y.; Li, X. Distribution and potential risk of heavy metals in sediments of the Three Gorges Reservoir: The relationship to environmental variables. Water 2018, 10, 1840. [CrossRef]

24. Przyborowski, Ł.; Łoboda, A.M.; Bialik, R.J. Experimental investigations of interactions between sand wave movements, flow structure, and individual aquatic plants in natural rivers: A case study of Potamogeton Pectinatus L. Water 2018, 10, 1166. [CrossRef]

(C) 2019 by the authors. Licensee MDPI, Basel, Switzerland. This article is an open access article distributed under the terms and conditions of the Creative Commons Attribution (CC BY) license (http://creativecommons.org/licenses/by/4.0/). 